\title{
Advice on good practice from the Standards Committee
}

\author{
J S Happel General practitioner, Ropley, Hampshire
}

\section{Author's abstract}

The role of the General Medical Council has changed over the last few years and this paper shows how the GMC now gives advice on good practice, as well as a warning against bad practice.

I thought it would be helpful to mention the role of the Standards Committee and to give a little background showing how our council advice has changed - and it has had to change especially in recent years - and to point up the need to base instruction to students not only on ethical principles but on the latest and most upto-date versions of the council's advice as shown in the GMC 'blue book' (1) and in our annual reports.

Our explicit power or duty to give positive advice to the profession is a very new one. Section 35 of the 1983 Medical Act tells us exactly what to do. It has been very carefully and quite simply worded and it is based on a section of the Merrison Report (2), headed 'The Establishment of High Standards of Professional Conduct'. Section 358, which sums up the view of the Merrison Committee shows that we were placed under a statutory duty to promote high standards of professional conduct. The word 'high' does not appear in that section in the Act but it was implied by the Merrison Report, the debates in Parliament and the parallel section which empowered us to promote high standards of medical education. But in omitting the word 'high' it at least gave statutory power to something we have done for a century or more, that is to send letters to individual doctors pointing out in no uncertain terms their low standards of professional conduct.

Our disciplinary powers go back to the original Medical Act of 1858 which set up the GMC. That was perhaps not drafted as well as it might have been, but when we recall that 17 previous bills had foundered in Parliament we realise that it was important to get something onto the statute book. In fact, the first

\section{Key words}

Medical ethics teaching; General Medical Council (Great Britain). doctor who was erased from the Register had to be put back on again because of a defect in the procedure. Defects in the 1858 Medical Act were put right in the 1886 Medical Act (some 30 years later) which became the pattern for the next 60 years or so, but even then the council was slow to take action against individual doctors and as late as $1889 \mathrm{Mr}$ John Marshall, President, spoke of 'the important relief afforded to the council by the independent action of such of the qualifying bodies as possess effective disciplinary powers' (3). He went on to urge those bodies to take action on their own account and so save the council trouble and expense, and a very real expense it was because until 1950 the whole council sat as the Disciplinary Committee.

By 1894 there was a change of policy. Thirteen doctors were erased that year and it was in that year that the council began to issue its famous Warning Notices to the profession. These simply consisted of reprints of general resolutions of the council. Here is part of one that was sent out in 1905: it sounds almost like a European Economic Community (EEC) directive. 'Whereas it has from time to time been made to appear to the General Medical Council that some registered medical practitioners have, with a view to their own gain and to the detriment of other practitioners' and so on, and it goes on about advertising and canvassing. The first paragraph ends: 'for the purpose of procuring persons to become their patients'. It goes on: 'And whereas in the opinion of the council such practices are contrary to the public o interest and discreditable to the profession of $\tilde{O}$ medicine. The council hereby give notice'. It says 代 further: 'that any registered medical practitioner 0 resorting to such practices thereby renders himself to be liable to be charged under the 29th section of the $\frac{C}{\mathbb{D}}$ Medical Act 1858 with infamous conduct in a $\stackrel{?}{?}$ professional respect' and to be erased from the Register. 7 That was the sort of thing that continued to be sent out $\bar{O}$ right until 1958. So it was no good doctors saying 'Lord, we didna ken' in the words of the Calvinists.

I qualified in 1947 and I well remember those $\frac{\varrho}{\sigma}$ warning notices - they had a definite terrorising effect. So had even coming to meet our President, 20 years $\delta$ ago, Lord Cohen. I first came to the GMC in 1965 as part of a British Medical Association (BMA) deputation 
from the Ethical Committee. On the way over there was a certain tension. I particularly was adjured to keep my place and hold my tongue. Our chairman was $\mathrm{Dr}$ Noy Scott and our committee secretary was the young Dr John Havard who, I remember, wore morning dress and a bowler hat for the occasion, but the bowler hat did not do us any good because Henry Cohen flayed into us straight away. All we had come to ask was: 'Please Sir, would it be all right if a consultant coming new to a hospital sent out just a wee letter to the GPs saying who he was, where we could get hold of him and his 'phone number'. Henry did not think this was at all a good idea. He said the 'new' consultant should get to work, work hard and cure a few bodies and souls and then he would become known. There was no need for this commercial traveller sort of thing. We had the greatest difficulty in persuading him otherwise.

The GMC 'blue book' (1) did not appear until 1966. In fact, it was only revamped to its present form in 1974, a mere 10 years ago. Part I sets out the disciplinary processes of the council and Part II the convictions and forms of professional misconduct which may lead doctors before the council. The beginnings of Part III came two years later in 1976, with supplementary advice about advertising, and in the following year there was similarly expanded advice on personal relationships with patients, doctors and sex, and professional confidence. In 1979 we had a major revision of those paragraphs and in 1980 we set out the new functions of the council following in the 1978 Medical Act. We then added a Part IV about health procedures, with which I myself have been closely involved. So that brings us up to the GMC which took office in November 1979. At its first meeting it elected a Committee of Professional Standards and Medical Ethics, which I have chaired ever since.

According to the standing orders of the council the function of the committee is to carry out what is set out in paragraph 5 of the 1978 Medical Act. The standing order goes on to say: 'On consideration of its reports, the council may decide to adopt that advice for issue to the profession'. In fact we got away with having our first report rubber-stamped before the council had shaken down fully, but since then I think on every major topic that we have brought forward we have had a wideranging discussion within the council. I think this has shown the council at its best. Many points have been made and I welcome those debates, not only because the text adjusted after such a discussion carries that much more weight, but because, as a cautious Lowlander I feel there is less chance of having dropped a clanger when it goes outside.

One of the more important points I want to make is that while traditionally the Warning Notices issued by the council concerned matters which might raise a question of serious professional misconduct, it has been left to the British Medical Association to give ethical advice on other matters, especially on matters of practice. But under section 5 of the 1978 Act which I have referred to earlier it is the council which is vested with the statutory power of giving guidance on all such matters, and I have to report that we have proceeded cautiously in these matters. In paragraph 356 of the Merrison Report (2) the members of that committee said they did not believe that everyone else at present concerned with medical ethics should then shut up shop. We in the country know that when a shop shuts there is less service, so also we in the council are far from believing that the BMA and other people should take a backward step in this area. At the same time we are now, through the Standards Committee, responsible for what goes into the GMC 'blue book' (1). So I have to report very briefly that in 1980 there was not time for much new matter, but in 1981 we revised the section on neglect of a doctor's personal responsibility for his patients. Let me say right at the beginning of the day that regardless of what you may read elsewhere the neglect of a doctor's own responsibility for the care and treatment of his patients is and will remain the primary concern of the GMC. Also in the 1981 issue of the blue book we revised generally the section on advertising and in particular the advice to doctors working for organisations which themselves advertise to the public - not an easy matter - and we prepared a new statement about the principles that should govern the reference of patients to specialists. That is reprinted in the issue of 1983 (1), which was an expanded edition and issued to the whole profession. Again we revised the section on Neglect (4), and for the first time we mention the question of a doctor endangering the welfare of his patients by persisting in independent practice of a branch of medicine in which he does not have the appropriate knowledge and skill and in which he has not acquired the necessary experience. Previously the GMC had stood off from that matter, thinking that it was something for the courts to determine. I mention it in particular because it shows the influence that the lay members of the GMC have had in establishing our policy; this was something about which they in particular felt strongly.

Also in this most recent edition of the blue book (1) we have included a new section on relationships with the drug industry, again not an easy thing to draft in brief form, and we have also included (5) a revised statement on professional confidence. Although this was a complete revision it is still based on the 1974 edition of the BMA Handbook (6). Inevitably the press concentrated on the section about girls under 16, and so it will interest you to read again what we did say as distinct from what we are alleged to have said (7). It is interesting to recall that this section was not, in fact, in our report to council in November 1982, which we thought was the last one before the publishing deadline. However, that deadline was extended for other reasons. In the meantime Dr Jeffrey Scott insisted that we debate this controversial subject and the final draft was prepared by learned counsel.

So much, then, for the 'blue book'. Also, now, we take the opportunity in our annual report to include 
some advice on current matters. In the 1981 Annual Report we mentioned for example, the important question of prescribing opioid drugs in private practice (8). In the 1982 Annual Report, which was published in September 1983, to coincide with our 125th anniversary, there is a new section on medical reports (9). It says that doctors may have been issuing reports which either suggest something false or omit some relevant material which is known to the doctor. It goes on to say: 'The council wishes to remind the profession of their responsibilities in this matter,' which is not so very different from 'The council hereby gives notice'. The last sentence makes clear what we are asking the profession to do. On the next page are our views about female circumcision (10) and in between the result of prolonged discussions with the skilled officials of the Inland Revenue, who wanted us to concede that in the ultimate the inspector should have the right of access to a doctor's clinical notes in private practice if he thought there was any question of a fiddle. While we were not prepared to concede that we did offer some advice at the end of the section (10).

These, then, are some of the things we have been discussing during the short time we have been in existence. I have tried to show how over recent years the advice given by the council has changed considerably, and how since 1979 we have had to become much more closely involved with current practice problems as distinct from punishing the wicked. Although ethical principles do not change, their application in practice must involve continuous adjustment as society develops and changes. That is why it is most important when giving instruction to students on these matters that we should not only stress the basic tenets but also the most up-to-date advice issued by the council, as set out in the 'blue book' and our annual reports.

\section{References}

(1) GMC. Professional conduct and discipline: fitness to practise. London: GMC, 1983.

(2) Report of the committee of inquiry into the regulation of the $\overrightarrow{\vec{A}}$ medical profession, (Merrison report). London: HMSO, 1975. (Cmd 6018)

(3) Marshall J. Presidential address to the General Medical Council, 1889.

(4) See reference (1): 10, 11.

(5) See reference (1): 18-20.

(6) British Medical Association. Medical ethics. London: BMA, 1974.

(7) See reference (1): 20.

(8) GMC. Annual report for 1981. London: GMC, 1982.

(9) GMC. Annual report for 1982. London: GMC, 1983: 40.

(10) See reference (9): 41 . 